DE GRUYTER

OPEN

\title{
APPLICATION OF THE DISTRIBUTED PLASTICITY CONCEPT IN QUICK NONLINEAR ANALYSIS OF REINFORCED CONCRETE SHEAR WALLS
}

\author{
F. S. Trifa ${ }^{a} *$, A. Cătărig ${ }^{b}$ \\ a, ${ }^{*}$ University of Oradea, Faculty of Civil Engineering and Architecture, 4, B.S. Delavrancea Street, Oradea, Romania, \\ e-mail: trisaco@gmail.com \\ ${ }^{\mathrm{b}}$ Technical University of Cluj-Napoca, Faculty of Civil Engineering, 15, C. Daicoviciu Street, Cluj-Napoca, Romania, \\ e-mail: AlexCatarig@mecon.utcluj.ro
}

Received: 15.03.2015 / Accepted: 30.03.2015 / Revised: 26.04.2015 / Available online: 31.05.2015

DOI: $10.1515 /$ jaes-2015-0014

KEY WORDS: Reinforced Concrete, Shear Wall, Nonlinear Analysis, Push-Over Analysis, Shear Deformations

\begin{abstract}
:
The paper presents a simplified calculation method to predict, as accurate as possible, the most important characteristics of the behaviour of the slender reinforced concrete shear walls in the inelastic range: failure mode, strength capacity, flexural and shear deformations, sectional and element ductility. The formulation is based on nonlinear beam element with taking into account the influence of shear, both on strength and stiffness of the wall. The principal parameters incorporated in the calculation model are: the rectangular shape of the cross section, the aspect ratio of the wall, the most accurate constitutive relationships for the compressed concrete and for the reinforcement steel, both in compression and in tension (including the strengthening of the steel after yielding), the variation of the Poisson ratio of the concrete, the amount and distribution of the vertical reinforcement. The model uses the concept of distributed (smeared) plasticity along the element and so the flexural deformations are computed by integrating the actual curvatures on the height of the wall. The shear deformations are also calculated, in agreement with the results of some recent experimental researches. The calculation method was then applied to two experimental wall specimens and their force - horizontal top displacement curves were plotted.
\end{abstract}

\section{INTRODUCTION}

Reinforced concrete shear walls are considered main structural members of the structures designed to carry the important lateral forces due to strong earthquake motions (Park and Paulay, 1975 and Paulay et al., 1990). Therefore, it is very important for these structural elements to yield in flexure and to have high values of the flexural displacements with no or little loss of strength capacity (Agent and Postelnicu, 1983).

As the well - known experimental investigation conducted by NUPEC (Nuclear Power Engineering Corporation, 1996) has revealed, an obvious inability to accurately predict the two main components of the reinforced concrete shear walls inelastic behaviour (maximum load and ultimate displacement) appeared to be associated with various models and calculation methods used. Thus, there is of great importance to use a calculation model able to accurately assess, not only the strength capacity of the structural walls, but also their displacements produced by the horizontal forces, especially in the inelastic range, but also to predict their failure modes. Subsequent experimental and theoretical researches have perfected improved calculation models of the cracked reinforced concrete elements, such as the modified compression field theory based are (Vecchio F. J., Collins M. P., 1986 and Palermo D., Vecchio F. J., 2002). Other researches (Ile N., Reynouard J. M., 2000 and 2005) have perfected a model for finite element analysis under cyclic loading based on the smeared crack approach, reasonable good results in simulating the most characteristic features of reinforced concrete shear walls being acquired. However, such calculation methods are very difficult to use in engineering practice because of their high degree of sophistication which requires a large computational capacity and a highly specialized software. As a result, the most common formulations are further

\footnotetext{
* Corresponding author.
} 
based on nonlinear beam elements for modelling the slender walls most frequently taking into account frequently only their flexural response. A number of recent experimental researches (Massone et al., 2004, Beyer et al., 2011) have shown up that, in the inelastic range, even the reinforced concrete slender walls may present important shear deformations, not only flexural ones, which had to be considered in a realistic assessment of their stiffness and ductility. As the performance-based design gains ground, it is important for structural designers to have at hand effective and simple to use calculation methods but also reliable in respect with the design purposes. This paper provides a simplified and quick calculation method of the reinforced concrete slender shear walls to take into account the aspects mentioned above.

\section{MATERIALS AND METHODS}

\subsection{Basic Assumptions}

Performed on the scheme of a vertical cantilever fixed at the base and loaded at the top with a constant axial force $(\mathrm{N})$ together with a horizontal one (S), monotonically increasing up to the failure, as shown in Figure 1, the calculation of the shear wall is based on the following assumptions (Trifa, 2012):

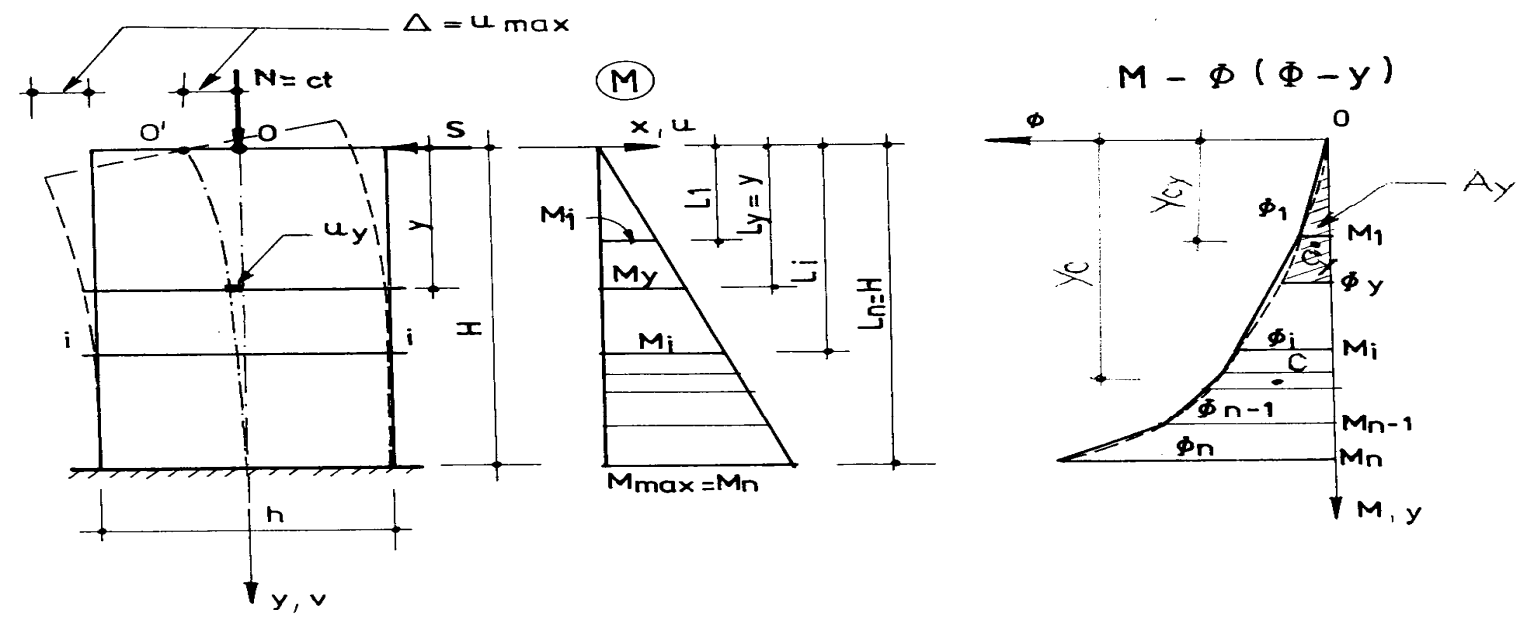

Figure 1. Shear wall. Forces, bending moment and curvature

- The linear distribution of the specific longitudinal strains $\varepsilon$ on the height $\mathrm{h}$ of the wall cross-section, at all loading stages, up to failure (Bernoulli's principle), as shown in Figure 2;

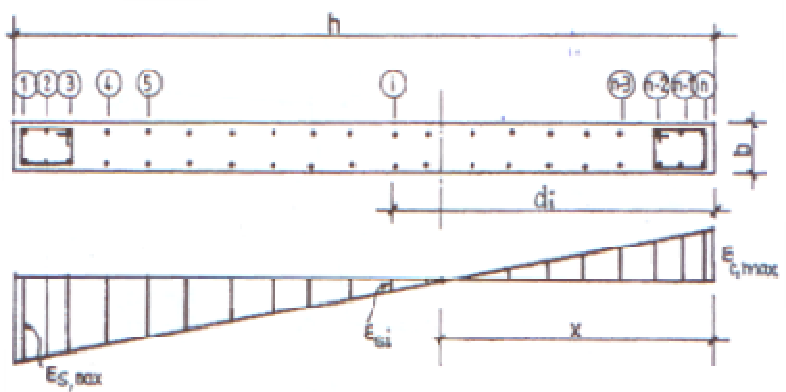

Figure 2. Strains in the rectangular cross-section

- The working out of the tensiled concrete after cracking;

- The use of a constitutive curve $\left(\sigma_{c}-\varepsilon_{c}\right)$ for the compressed concrete with a parabolic shape (Agent and Postelnicu, 1983, EN 1992-1-1: 2004) to consider the degradation of the compressive strength of the concrete before failure (Figure 3);

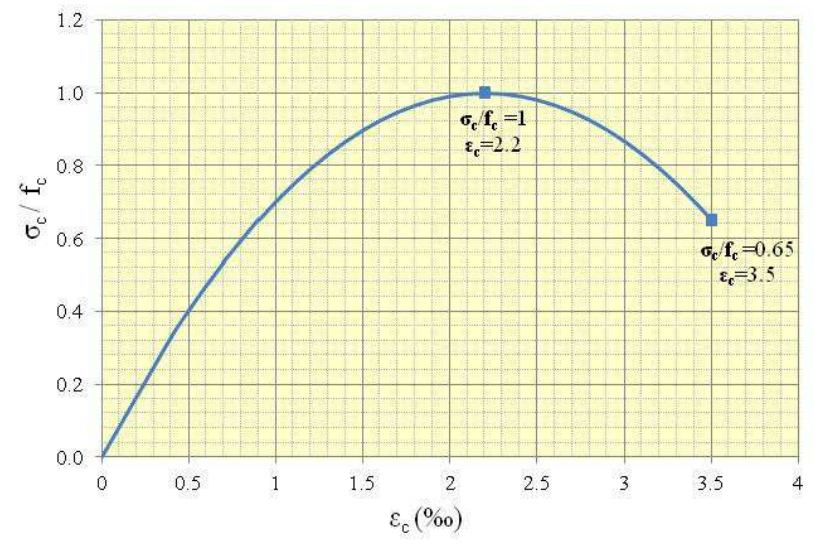

Figure 3. Constitutive curve of the compressed concrete

- The use for the contraction coefficient of the concrete $v$ (Poisson ratio) a variation law as shown in Figure 4 (Brînzan and Trifa, 1988); 


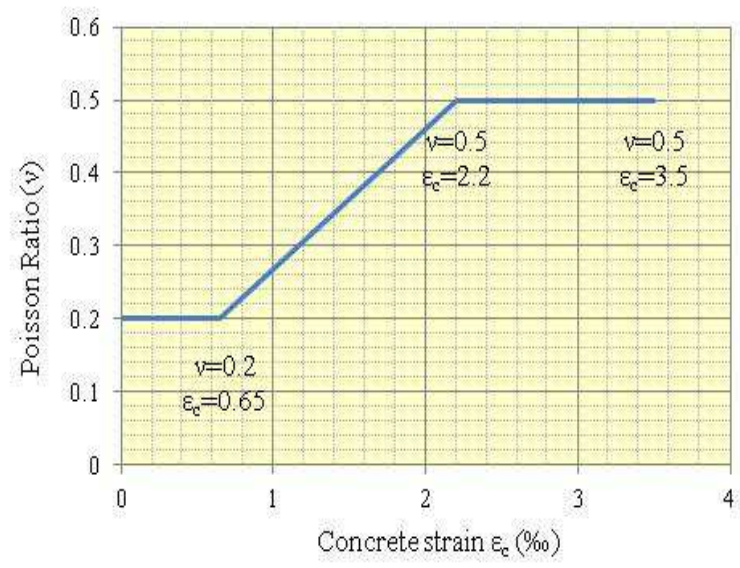

Figure 4. Variation law of Poisson ratio for the compressed concrete

- The use for the constitutive curve $\left(\sigma_{\mathrm{s}}-\varepsilon_{\mathrm{s}}\right)$ of the reinforcement steel in tension/compression a bilinear diagram (Figure 5) to consider the steel hardening after the yielding point $\left(\varepsilon_{\mathrm{sy}}\right)$, namely: $\sigma_{\mathrm{s}}>\mathrm{f}_{\mathrm{sy}}$ for any value of the specific strain of longitudinal reinforcement (in tension or in compression) $\varepsilon_{\mathrm{si}}$ in the range $\left[\varepsilon_{\mathrm{sy}}, \varepsilon_{\mathrm{su}}\right]$ (Brinzan and Trifa, 1988);

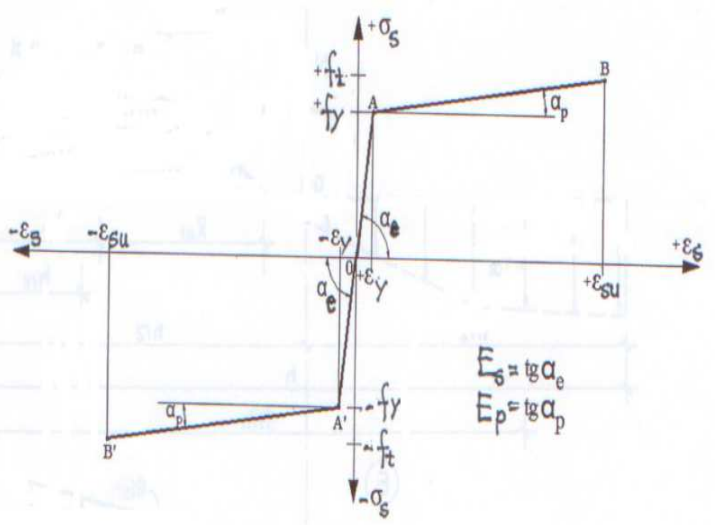

Figure 5. Constitutive curve for steel reinforcement in tension/compression

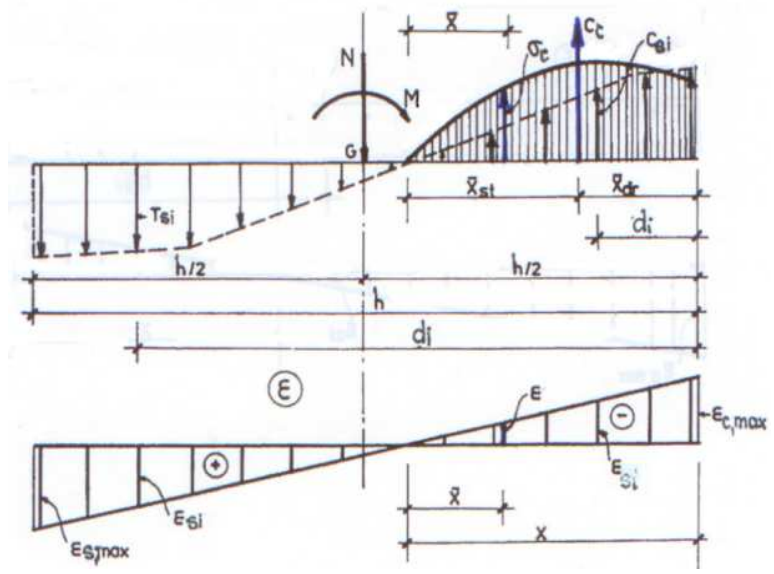

Figure 6. Internal forces in the eccentrically compressed crosssection

- The use in the angle shearing-deformation calculus of the secant modulus of elasticity of the concrete in compression obtained from the characteristic curve from Figure 3, as follows: $\mathrm{E}_{\mathrm{c}}^{\prime}=\sigma_{\mathrm{c}} / \varepsilon_{\mathrm{c}}$;

- The neglect of second order geometrical effects.

\subsection{Calculation of the strength capacity in bending of the shear wall}

For a given value of the strain at the most compressed concrete fibre of the cross-section (ec, max), the internal forces shown in Figure 6 must satisfy the equilibrium equations (Trifa and Prada, 2000):

$$
\begin{gathered}
\mathrm{N}=\mathrm{C}_{\mathrm{c}}+\sum_{\mathrm{i}} \mathrm{C}_{\mathrm{si}}-\sum_{\mathrm{i}} \mathrm{T}_{\mathrm{si}} \\
\mathrm{M}=\mathrm{C}_{\mathrm{c}}\left(\frac{\mathrm{h}}{2}-\overline{\mathrm{x}}_{\mathrm{dr}}\right)+\sum_{\mathrm{i}} \mathrm{C}_{\mathrm{si}}\left(\frac{\mathrm{h}}{2}-\mathrm{d}_{\mathrm{i}}\right)+\sum_{\mathrm{i}} \mathrm{T}_{\mathrm{si}}\left(\mathrm{d}_{\mathrm{i}}-\frac{\mathrm{h}}{2}\right)
\end{gathered}
$$

where: $\quad \sum_{\mathrm{i}} \mathrm{C}_{\mathrm{si}}=\mathrm{C}_{\mathrm{s}}$ represents the resultant of the forces produced in the compressed reinforcement bars; $\sum_{\mathrm{i}} \mathrm{T}_{\mathrm{si}}=\mathrm{T}_{\mathrm{S}}$ represents the resultant of the forces produced in the tensiled reinforcement bars; $\mathrm{C}_{\mathrm{c}}$ is the resultant of the stresses from the compressed concrete area of the cross-section.

As shown (Trifa and Prada, 2000), the internal forces and the length $\overline{\mathrm{X}}_{\mathrm{dr}}$ mentioned above have the following expressions:

$$
\mathrm{C}_{\mathrm{c}}=\int_{0}^{\mathrm{x}} \mathrm{b} \sigma_{\mathrm{c}}(\overline{\mathrm{x}}) \mathrm{d} \overline{\mathrm{x}}=\mathrm{bxf}_{\mathrm{c}} \frac{\varepsilon_{\mathrm{c}, \max }}{\varepsilon_{\mathrm{c} 0}}\left(1-\frac{1}{3} \frac{\varepsilon_{\mathrm{c}, \max }}{\varepsilon_{\mathrm{c} 0}}\right)
$$

with $\varepsilon_{\mathrm{c} 0}=2.2 \%$ 
$\mathrm{C}_{\mathrm{s}}=\sum_{\mathrm{i}=1}^{\mathrm{k}} \mathrm{C}_{\mathrm{si}}=\sum_{\mathrm{i}=1}^{\mathrm{k}} \mathrm{A}_{\mathrm{si}} \sigma_{\mathrm{si}} \quad(\mathrm{k}=$ the number of compressed

pairs of reinforcement bars)

$\mathrm{T}_{\mathrm{s}}=\sum_{\mathrm{i}=1}^{\mathrm{j}} \mathrm{T}_{\mathrm{si}}=\sum_{\mathrm{i}=1}^{\mathrm{j}} \mathrm{A}_{\mathrm{si}} \sigma_{\mathrm{si}} \quad(\mathrm{j}=$ the number of tensioned pairs

of reinforcement bars)

$$
\overline{\mathrm{x}}_{\mathrm{dr}}=\frac{4-\alpha}{4(3-\alpha)} \mathrm{x} \text {, with } \alpha=\frac{\varepsilon_{\mathrm{c}, \max }}{\varepsilon_{\mathrm{c} 0}}
$$

Replacing (3), (4), (5) and (6) in (1), it results:

with

$$
\mathrm{N}=\omega \mathrm{b} \times \mathrm{f}_{\mathrm{c}}+\sum_{\mathrm{i}=1}^{\mathrm{k}} \mathrm{A}_{\mathrm{si}} \sigma_{\mathrm{si}}-\sum_{\mathrm{i}=1}^{\mathrm{j}} \mathrm{A}_{\mathrm{si}} \sigma_{\mathrm{si}}
$$

$$
\omega=\alpha(1-\alpha / 3)
$$

Noting that, from Figure 2, $\varepsilon_{\mathrm{si}}=\varepsilon_{\mathrm{c}, \max } \frac{\mathrm{d}_{\mathrm{i}}-\mathrm{x}}{\mathrm{x}}$, it results that the relation (7) has two unknowns: $\mathrm{x}$ and $\varepsilon_{\mathrm{c}, \max }$.

Giving increasing values to $\varepsilon_{\mathrm{c}, \max }$ until it reaches the ultimate one $(3.5 \%)$, corresponding to the failure of the compressed concrete, $\varepsilon_{\mathrm{c}, \max }$ is eliminated and the relation (7) turns into a quadratic equation with the unknown $\mathrm{x}$ which gives the position of the neutral axis of the cross-section for the loading stage corresponding to $\varepsilon_{c, \max }$ value. The calculus is performed by successive attempts for each $\varepsilon_{\mathrm{c} \text {,max }}$ given value, until the equilibrium equation (1) is satisfied. Once the value of $x$ determined, $\varepsilon_{\mathrm{si}}, \sigma_{\mathrm{si}}, \mathrm{C}_{\mathrm{si}}, \mathrm{T}_{\mathrm{si}}$ and $\mathrm{C}_{\mathrm{c}}$ can be further calculated as shown above and, substituted in (2), the value of the bending moment of the wall cross-section, corresponding to the given value of $\varepsilon_{\mathrm{c}, \max }$, is obtained.

The curvature $\Phi$ and the bending stiffness modulus $\left(\mathrm{E}_{\mathrm{c}} \mathrm{I}_{\mathrm{c}}\right)$ of the base cross-section are then calculated at the same loading stage with the well-known formulae (Brînzan and Trifa, 1988 and Bia, Ille et al., 1983):

$$
\Phi=\frac{\varepsilon_{\mathrm{c}}}{\mathrm{x}} ; \quad \mathrm{E}_{\mathrm{c}} \mathrm{I}_{\mathrm{c}}=\frac{\mathrm{M}}{\Phi}
$$

It must be noted that, for $\varepsilon_{\mathrm{c}, \max }=3.5 \%$ and $\varepsilon_{\mathrm{s}, \max }<\varepsilon_{\mathrm{su}}$, the section fails through crushing of the compressed concrete and for $\varepsilon_{\mathrm{s}, \max }=\varepsilon_{\mathrm{su}}$ and $\varepsilon_{\mathrm{c}, \max }<3.5 \%$, the section fails through steel rebars fracture, resulting in both cases the maximum value of the bending moment (i.e. flexural strength capacity of the wall cross-section).

\subsection{Calculation of the horizontal displacements of the wall}

Neglecting the displacement due to the sliding along the base cross-section, the total horizontal displacement of the wall at top can be written:

$$
\Delta=\Delta_{\mathrm{f}}+\Delta_{\mathrm{s}}
$$

where: $\Delta_{\mathrm{f}}$ is the flexural displacement and $\Delta_{\mathrm{s}}$ is the displacement due to shear.

\subsubsection{Calculation of the flexural horizontal displacement $\left(\Delta_{\mathrm{f}}\right)$}

In Figure 1 are presented the variations along the height of the wall, both of the bending moment and of the curvature. The bending moment in a cross-section located at the distance $\mathrm{y}=\mathrm{L}_{\mathrm{y}}$ from the top of the wall is:

$$
M_{y}=M_{\max } \frac{L_{y}}{H}=M_{\max } \frac{y}{H}
$$

where: $\mathbf{M}_{\max }$ is the bending moment in the base cross-section.

It results that the bending stiffness modulus of the cross-section and also the curvature vary from one section to another, i.e.: $\mathrm{E}_{\mathrm{c}} \mathrm{I}_{\mathrm{c}}$ $=\left(E_{c} I_{c}\right)_{y}$ and $\Phi=\Phi_{y}$. To determine the horizontal displacement $\mathrm{u}_{\mathrm{y}}$ of a certain section of the wall due to flexure, at the considered loading stage, it will be used the integration of the curvatures of the cross-sections on the height of the wall, as follows:

$$
\begin{aligned}
\mathrm{u}_{\mathrm{f}, \mathrm{y}} & =-\int_{0}^{\mathrm{y}} \mathrm{dy}\left[\int_{0}^{\mathrm{y}} \Phi_{\mathrm{y}} \mathrm{dy}\right]=-\int_{0}^{\mathrm{y}} \mathrm{dy} \int_{0}^{\mathrm{y}} \Phi_{\mathrm{y}} \mathrm{dy}= \\
& =\left(\mathrm{y}_{\mathrm{C}_{\mathrm{y}}}-\mathrm{y}\right) \mathrm{A}_{\mathrm{y}}^{\Phi}+\left(\mathrm{y}-\mathrm{y}_{\mathrm{C}}\right) \mathrm{A}^{\Phi}
\end{aligned}
$$

in which: $\Phi_{y}=\frac{1}{\rho_{y}}=\frac{M_{y}}{\left(E_{c} I_{c}\right)_{y}}$

where: $\rho_{\mathrm{y}}$ is the radius of the curvature of the cross-section

$$
\mathrm{A}_{\mathrm{y}}^{\Phi}=\text { the area bounded by the portion of the function }
$$

$\Phi_{\mathrm{y}}$ graph from above the actual cross-section

$$
\mathrm{y}_{\mathrm{Cy}}=\text { the distance from the centroid } \mathrm{C}_{\mathrm{y}} \text { of area } \mathrm{A}_{\mathrm{y}}^{\Phi} \text { to }
$$

Ox axis.

Customizing the relation (10) by taking $\mathrm{y}=\mathrm{H}$, it results the top horizontal displacement of the wall due to flexure as follows:

$$
\Delta_{\mathrm{f}}=\mathrm{u}_{\mathrm{f}, \max }=-\int_{0}^{\mathrm{H}} \mathrm{dy} \int_{0}^{\mathrm{H}} \Phi_{\mathrm{y}} \mathrm{dy}=-\mathrm{y}_{\mathrm{C}} \mathrm{A}^{\Phi}
$$

where: $\quad y_{C}=$ the coordinate of the centroid of the curvature ( $\Phi)$ chart from the entire height of the wall

$\mathrm{A}^{\Phi}=\Phi$ chart area from the height of the wall in the considered loading stage $\left(\varepsilon_{\mathrm{c}, \max }<\varepsilon_{\mathrm{cu}}\right)$

$\mathrm{y}_{\mathrm{C}_{\mathrm{y}}} \mathrm{A}_{\mathrm{y}}^{\Phi}=$ the statical moment of the area $\mathrm{A}_{\mathrm{y}}^{\Phi}$

related to the actual cross-section, calculated to the top of the wall.

\subsubsection{Calculation of the shear horizontal displacement $\left(\Delta_{\mathrm{s}}\right)$}

We shall further determine the shear displacement of the wall in a simplified manner, by using the internal forces of the crosssection for assessing the average angle of shearing-deformation $\gamma_{\mathrm{m}}$. In the Theory of Elasticity (Bia, Ille et al., 1983) $\gamma_{\mathrm{m}}$ is given by: 


$$
\gamma_{\mathrm{m}}=\frac{\tau_{\mathrm{c}}}{\mathrm{E}_{\mathrm{sh}}}
$$

Applying Juravski formula for the shear stress $\tau_{\mathrm{c}}$ and replacing it in (13), it results:

$$
\gamma_{\mathrm{m}}=\frac{1}{\mathrm{E}_{\mathrm{sh}}} \frac{\mathrm{VS}_{0}}{\mathrm{bI}_{\mathrm{g}}}
$$

where: $\quad \mathrm{V}=$ the shear force;

$\mathrm{S}_{0}=$ the statical moment of the compressed/tensiled zone of the cross-section calculated to the neutral axis;

$\mathrm{E}_{\mathrm{sh}}=$ the modulus of elasticity in shear of the material.

Through successive transformations, it comes:

$$
\gamma_{\mathrm{m}}=\frac{1}{\frac{\mathrm{E}_{\mathrm{c}}^{\prime}}{2(1+\mathrm{v})}} \frac{\mathrm{VS}_{0}}{\mathrm{bI}_{\mathrm{g}}}=\frac{2(1+\mathrm{v})}{\mathrm{E}_{\mathrm{c}}^{\prime}} \frac{\mathrm{VS}_{0}}{\mathrm{bI}_{\mathrm{g}}}=\frac{\varphi}{\mathrm{E}_{\mathrm{c}}^{\prime}} \frac{\mathrm{VS}_{0}}{\mathrm{bI}_{\mathrm{g}}}
$$

where: $\quad \varphi=2(1+v)$

$\mathrm{E}_{\mathrm{c}}^{\prime}=$ the secant modulus of elasticity of the compressed concrete.

The lever arm of the internal forces can be approximated as follows:

$$
\mathrm{z} \cong \frac{\mathrm{M}}{\mathrm{C}}=\frac{\mathrm{M}}{\mathrm{C}_{\mathrm{s}}+\mathrm{C}_{\mathrm{c}}}
$$

Using the expression of $\mathrm{z}$ established (Bia, Ille et al., 1983) for the beams with homogeneous cross-section subjected to bending, it can be written:

$\mathrm{z}=\frac{\mathrm{I}_{\mathrm{g}}}{\mathrm{S}_{0}} \cong \frac{\mathrm{M}}{\mathrm{C}_{\mathrm{s}}+\mathrm{C}_{\mathrm{c}}}$, from where: $\mathrm{S}_{0} \cong\left(\mathrm{C}_{\mathrm{s}}+\mathrm{C}_{\mathrm{c}}\right) \frac{\mathrm{I}_{\mathrm{g}}}{\mathrm{M}}$ and:

$\frac{M}{I_{g}}=\frac{M}{E_{c}^{\prime} I_{g}} E_{c}^{\prime}=\Phi E_{c}^{\prime}=\frac{\varepsilon_{c}}{x} E_{c}^{\prime}=\frac{\sigma_{c}}{x}$

Replacing in (15), we get:

$\gamma_{\mathrm{m}}=\frac{\varphi}{\mathrm{E}_{\mathrm{c}}^{\prime}} \frac{\mathrm{V}}{\mathrm{b}} \frac{\mathrm{S}_{0}}{\mathrm{I}_{\mathrm{g}}} \cong \frac{\varphi}{\mathrm{E}_{\mathrm{c}}^{\prime}} \frac{\mathrm{V}}{\mathrm{b}} \frac{\left(\mathrm{C}_{\mathrm{s}}+\mathrm{C}_{\mathrm{c}}\right) \mathrm{x}}{\mathrm{I}_{\mathrm{g}} \sigma_{\mathrm{c}}}=\varphi \frac{\left(\mathrm{C}_{\mathrm{s}}+\mathrm{C}_{\mathrm{c}}\right) \mathrm{x}}{\mathrm{b} \sigma_{\mathrm{c}} \mathrm{E}_{\mathrm{c}}^{\prime} \mathrm{I}_{\mathrm{g}}} \mathrm{V}$

Since the shear force is constant on $\mathrm{H}$ but the other parameters vary the maximum horizontal shear displacement at the top of the wall results as follows:

$$
\Delta_{\mathrm{s}}=\mathrm{u}_{\mathrm{s}, \max }=\int_{0}^{\mathrm{H}} \gamma_{\mathrm{m}} \mathrm{dy}=\mathrm{V} \int_{0}^{\mathrm{H}} \varphi \frac{\left(\mathrm{C}_{\mathrm{s}}+\mathrm{C}_{\mathrm{c}}\right) \mathrm{x}}{\mathrm{b} \sigma_{\mathrm{c}} \mathrm{E}_{\mathrm{c}}^{\prime} \mathrm{I}_{\mathrm{g}}}
$$

It must be noticed that the variation on the height of the wall of $\mathrm{C}_{\mathrm{s}}, \mathrm{C}_{\mathrm{c}}, \mathrm{x}, \sigma_{\mathrm{c}}, \mathrm{E}_{\mathrm{c}}^{\prime}$ is due to the variation of the bending moment and it becomes an obvious conclusion that, despite of a constant shear force on the height of the wall, the shear displacements vary, their values being related to the flexural stiffness degradation, fact which had been reported by recent experimental researches (Massone et al., 2004).

\subsection{Application of the Method}

The method described above was applied to the calculation of two experimental wall specimens tested in INCERC (Building Research Institute) Bucharest laboratory (Brînzan and Trifa, 1988). In Figure 7 are presented the general view of the structure and the way of loading. Each of the two experimental specimens consisted of two twin reinforced concrete shear walls connected at the top by a reinforced concrete plate simulating an actual slab.

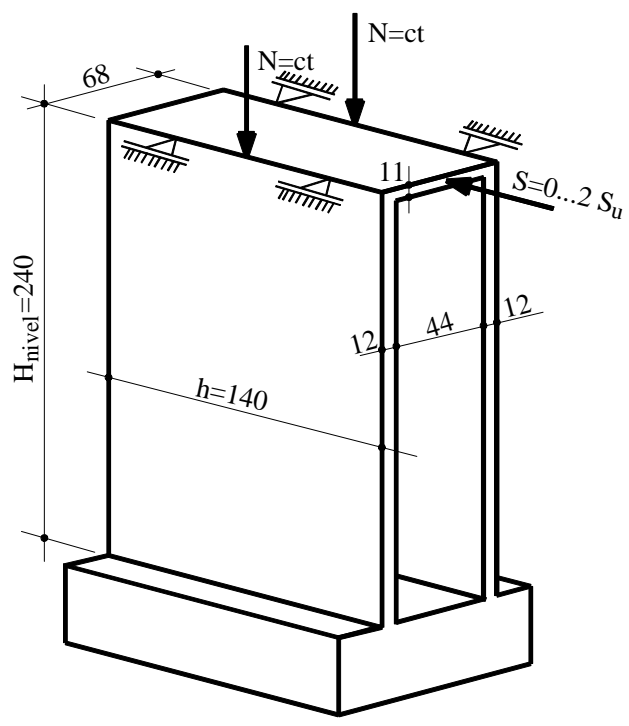

Figure 7. Experimental specimens. General view and loading

The reinforcement of each of the twin walls was as shown in Figure 8 and the properties of the steel rebars were those presented in Table 1 .

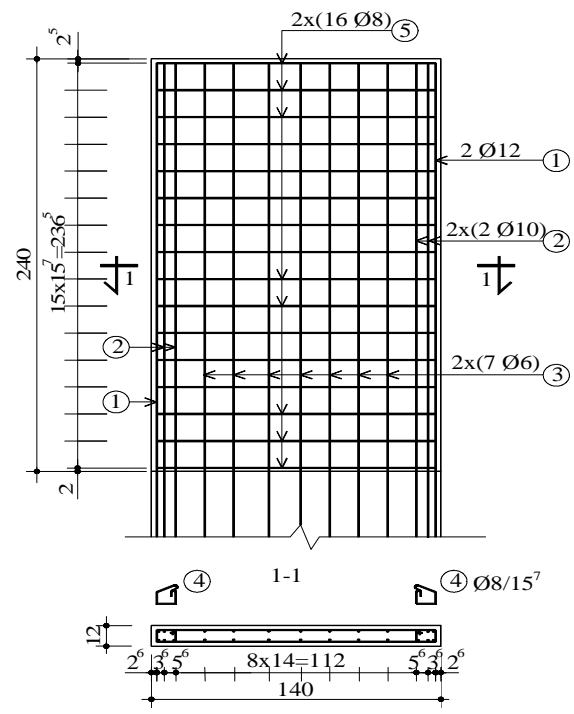

Figure 8. Reinforcement of the wall specimens 


\begin{tabular}{|c|c|c|c|c|c|c|}
\hline Bar size & Diameter & $\begin{array}{c}\varepsilon_{s y} \\
(\% o)\end{array}$ & $\begin{array}{c}\varepsilon s u \\
(\% o)\end{array}$ & $\begin{array}{c}\mathrm{f}_{\mathrm{sy}} \\
(\mathrm{MPa})\end{array}$ & $\begin{array}{c}\mathrm{f}_{\mathrm{st}} \\
(\mathrm{MPa})\end{array}$ & $\begin{array}{c}\mathrm{E}_{s} \\
(\mathrm{MPa})\end{array}$ \\
\hline 1 & 10 & \multirow{4}{*}{1.28} & \multirow{4}{*}{30} & \multirow{4}{*}{270} & \multirow{4}{*}{420} & \multirow{5}{*}{210} \\
\hline 2 & 8 & & & & & \\
\hline 4 & 8 & & & & & \\
\hline 5 & 8 & & & & & \\
\hline 3 & 6 & 1.68 & 30 & 350 & 530 & \\
\hline
\end{tabular}

Table 1. Steel reinforcement material properties

The strength of the concrete for the two specimens was: $\mathrm{fc}=$ 15.0 $\mathrm{MPa}$ for specimen D21 and $\mathrm{fc}=12.6 \mathrm{MPa}$ for specimen D22. The computed strength capacities in bending of each wall of the two specimens are presented in Table 2 and the comparison with the experimental strength capacities comes out from Table 3 .

\begin{tabular}{ccccc}
\hline \multirow{2}{*}{ Specimen } & Wall & $\begin{array}{c}\mathrm{M}_{\text {calc }} \\
{[\mathrm{kNm}]}\end{array}$ & $\begin{array}{c}\mathrm{S}_{\text {calc }} \\
{[\mathrm{kN}]}\end{array}$ & $\begin{array}{c}\mathrm{M}_{\text {exp }} / \\
\mathrm{M}_{\text {calc }}\end{array}$ \\
\hline \multirow{2}{*}{$\mathrm{D}_{21}$} & $\mathrm{D}_{21}$ & 589,0 & 261.8 & 0.98 \\
\cline { 2 - 5 } & $\mathrm{D}_{21}$ & 589.0 & 261.8 & 0.98 \\
\hline \multirow{2}{*}{$\mathrm{D}_{22}$} & $\mathrm{D}_{22}$ & 537.6 & 238.9 & 0.92 \\
\cline { 2 - 5 } & $\mathrm{D}_{22}$ & 537.6 & 238.9 & 0.92 \\
\hline
\end{tabular}

Table 2. Computed strength capacities

\begin{tabular}{ccccccc}
\hline Specimen & Wall & $\begin{array}{c}\mathrm{S}_{\exp } \\
{[\mathrm{kN}]}\end{array}$ & $\begin{array}{c}\mathrm{S}_{\exp } \mathrm{xH} \\
{[\mathrm{kNm}]}\end{array}$ & $\begin{array}{c}\Delta_{\mathrm{u}}^{\exp } \\
{[\mathrm{mm}]}\end{array}$ & $\begin{array}{c}\mathrm{N} \mathrm{x}_{\mathrm{u}}^{\mathrm{Exp}} \\
{[\mathrm{kNm}]}\end{array}$ & $\begin{array}{c}\mathrm{M}_{\exp } \\
{[\mathrm{kNm}]}\end{array}$ \\
\hline \multirow{2}{*}{$\mathrm{D}_{21}$} & $\mathrm{D}_{21}^{\prime}$ & 250 & 562.50 & 18.46 & 14.86 & 577.36 \\
\cline { 2 - 7 } & $\mathrm{D}_{21}^{\prime \prime}$ & 250 & 562.50 & 18.56 & 14.94 & 577.44 \\
\hline \multirow{2}{*}{$\mathrm{D}_{22}$} & $\mathrm{D}_{22}^{\prime}$ & 215 & 483.75 & 12.60 & 9.20 & 492.95 \\
\cline { 2 - 7 } & $\mathrm{D}_{22}^{\prime \prime}$ & 215 & 483.75 & 13.95 & 10.18 & 493.93 \\
\hline
\end{tabular}

Table 3. Experimental strength capacities

The push-over curves $(\mathrm{S}-\Delta)$ computed for a wall of the two specimens are presented in Figure 9 and Figure 10, where are separately plotted the variation of the two components of the top horizontal displacement, due to flexure and shear.

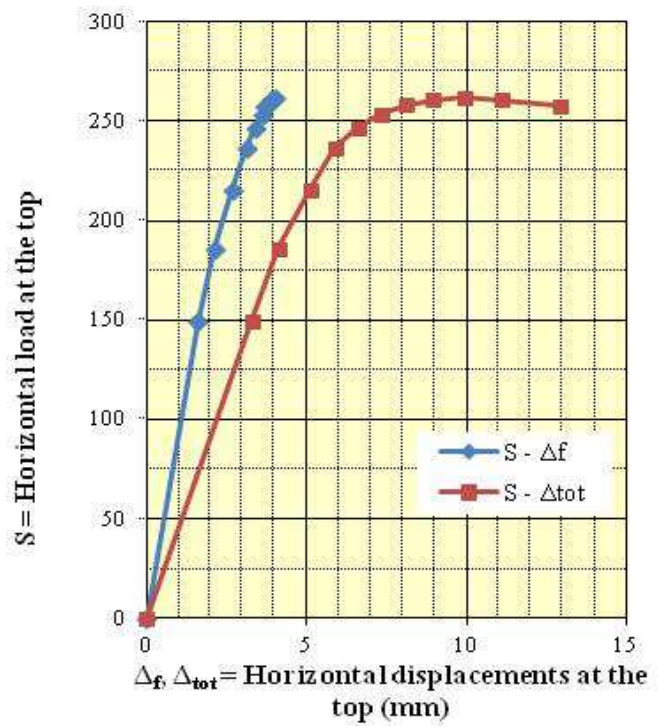

Figure 9. Shear Wall $\mathrm{D}_{21}$. Computed push-over $(\mathrm{S}-\Delta)$ curve

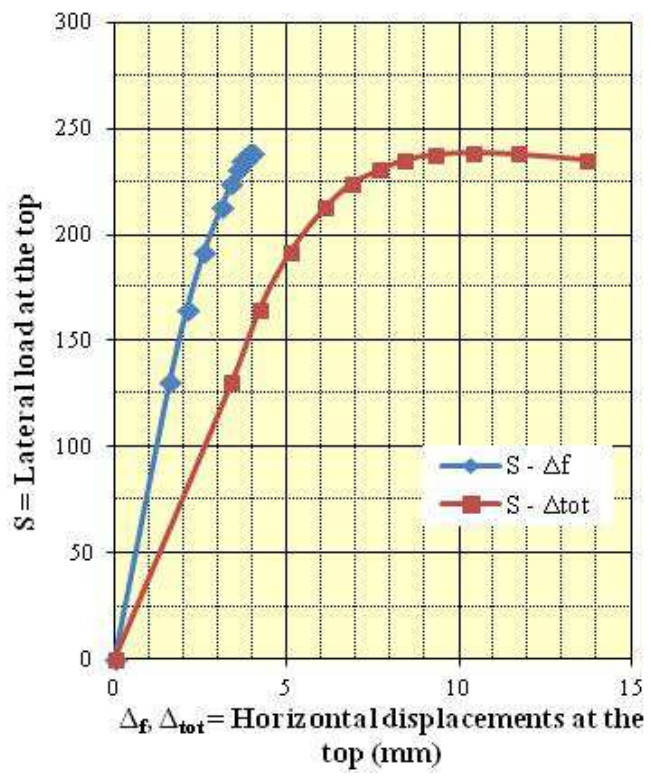

Figure 10. Shear Wall $\mathrm{D}_{22}$. Computed push-over $(\mathrm{S}-\Delta)$ curve

In Figure 11 and Figure 12 are presented the $(\mathrm{S}-\Delta)$ computed vs. experimental push-over curves for the two specimens. 


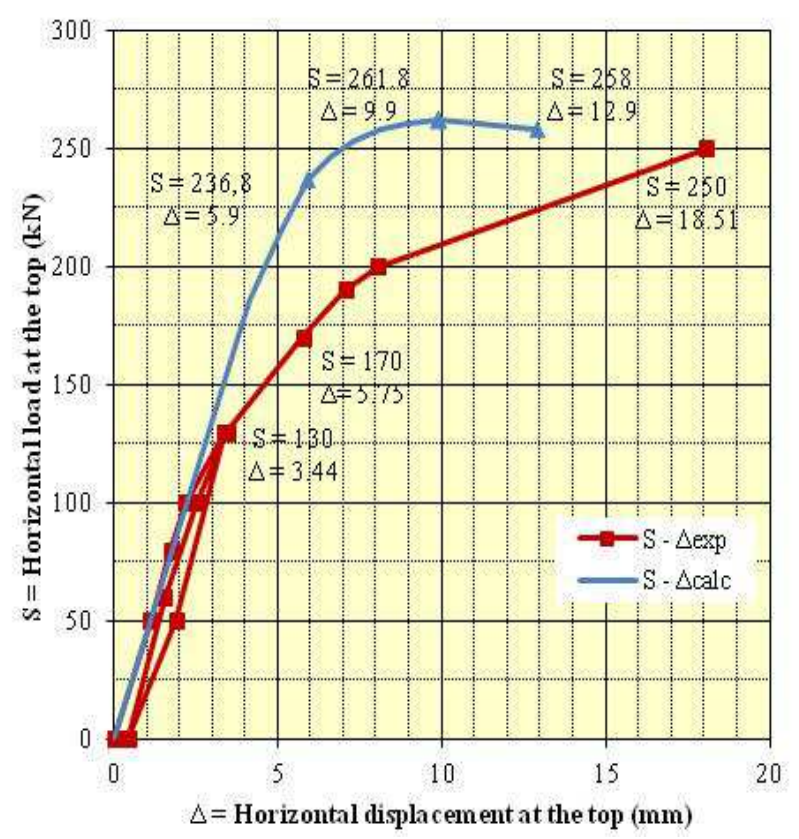

Figure 11. Shear Wall $D_{21}$. Computed vs. Experimental $(\mathrm{S}-\Delta)$ curves

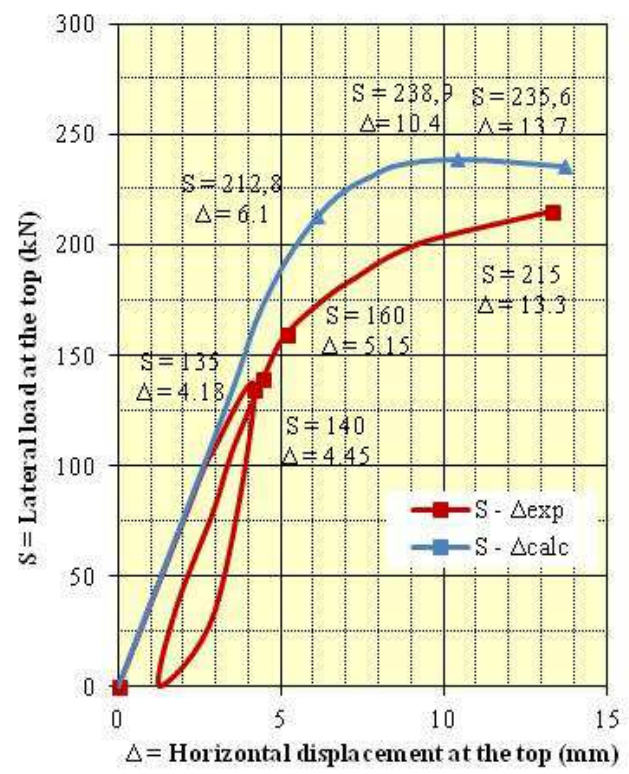

Figure 12. Shear Wall $\mathrm{D}_{22}$. Computed vs. Experimental $(\mathrm{S}-\Delta)$ curves

In Tables 4 and 5 are presented the values of the computed and the experimental displacements and ductilities resulting from computed and experimental force-displacement curves, as well as the values of the energy dissipation factor $(\psi)$.

\begin{tabular}{|c|c|c|c|c|c|c|c|}
\hline Specimen & Wall & $\begin{array}{l}\Delta_{\mathrm{y}}^{\mathrm{calc}} \\
(\mathrm{mm})\end{array}$ & $\frac{\Delta_{\mathrm{y}}^{\mathrm{cslc}}}{\mathrm{H}}$ & $\begin{array}{l}\Delta_{\mathrm{u}}^{\mathrm{calc}} \\
(\mathrm{mm})\end{array}$ & $\frac{\Delta_{\mathrm{u}}^{\mathrm{calc}}}{H}$ & $\left.\mu_{\Delta}^{\mathrm{calc}} 1\right)$ & $\Psi^{\text {calc }}$ \\
\hline \multirow{2}{*}{$\mathrm{D}_{21}$} & $\mathrm{D}_{21}$ & \multirow{2}{*}{5.9} & 1 & \multirow{2}{*}{12.9} & 1 & \multirow{2}{*}{2.19} & \multirow{2}{*}{0.54} \\
\hline & $\mathrm{D}_{21}$ & & 381 & & $\overline{174}$ & & \\
\hline \multirow{2}{*}{$\mathrm{D}_{22}$} & $\mathrm{D}_{22}$ & \multirow{2}{*}{6.1} & 1 & \multirow{2}{*}{13.7} & 1 & \multirow{2}{*}{2.25} & \multirow{2}{*}{0.53} \\
\hline & $\mathrm{D}_{22}$ & & 369 & & 164 & & \\
\hline
\end{tabular}

Table 4. Computed displacements and ductilities

\begin{tabular}{|c|c|c|c|c|c|c|c|}
\hline Specimen & Wall & $\begin{array}{l}\Delta_{y}^{\exp } \\
(\mathrm{mm})\end{array}$ & $\frac{\Delta_{y}^{\exp }}{H}$ & $\begin{array}{l}\Delta_{\mathrm{u}}^{\exp } \\
(\mathrm{mm})\end{array}$ & $\frac{\Delta_{u}^{\exp }}{\mathrm{H}}$ & $\mu_{\Delta}^{\exp 1)}$ & $\Psi^{\exp 2)}$ \\
\hline \multirow{2}{*}{$\mathrm{D}_{21}$} & $\mathrm{D}_{21}^{\prime}$ & 6.65 & $1 / 333$ & 18.56 & $1 / 121$ & 2.79 & 0.47 \\
\hline & $\mathrm{D}_{21}$ & 4.85 & $1 / 464$ & 18.46 & $1 / 122$ & 3.81 & 0.39 \\
\hline \multirow{2}{*}{$\mathrm{D}_{22}$} & $\mathrm{D}_{22}$ & 6.35 & $1 / 354$ & 13.95 & $1 / 161$ & 2.20 & 0.54 \\
\hline & $\mathrm{D}_{22}$ & 6.25 & $1 / 360$ & 12.6 & $1 / 179$ & 2.02 & 0.57 \\
\hline
\end{tabular}

Table 5. Experimental displacements and ductilities

Regarding the strains in the extreme points of the base cross sections of the experimental shear walls, in Figures $13-16$ are displayed the calculated variations of the concrete strain in the most compressed point $\left(\varepsilon_{\mathrm{c}}\right)$ and of the strain in the most tensioned reinforcement bars $\left(\varepsilon_{\mathrm{s}}\right)$.

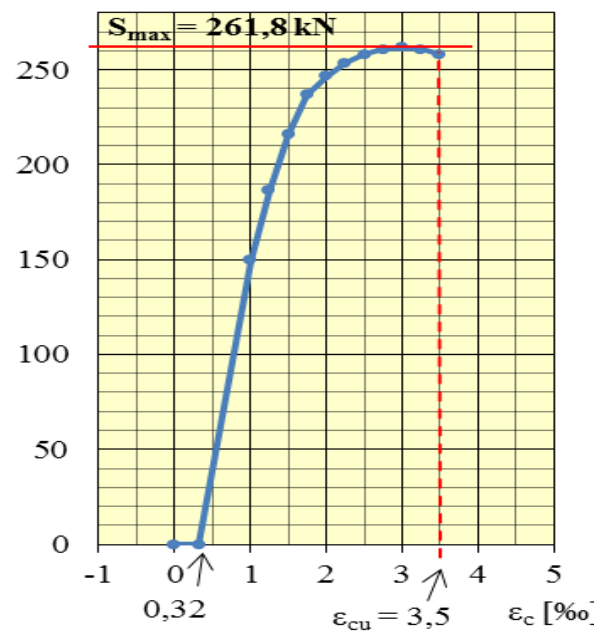

Figure 13. Shear Wall $D_{21}$. Computed $\left(S-\varepsilon_{c}\right)$ curve for the most compressed point of the base section 


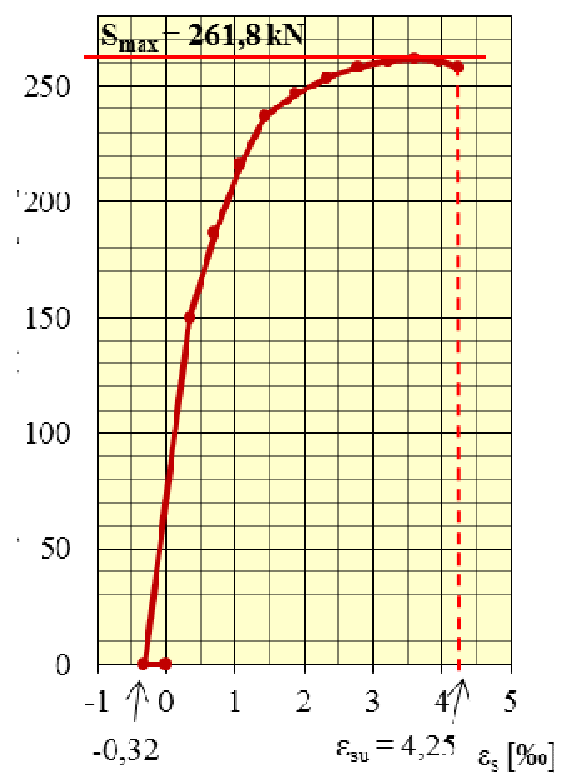

Figure 14. Shear Wall $\mathrm{D}_{21}$. Computed $\left(\mathrm{S}-\varepsilon_{\mathrm{s}}\right)$ curve for the most tensioned reinforcement bars of the base section

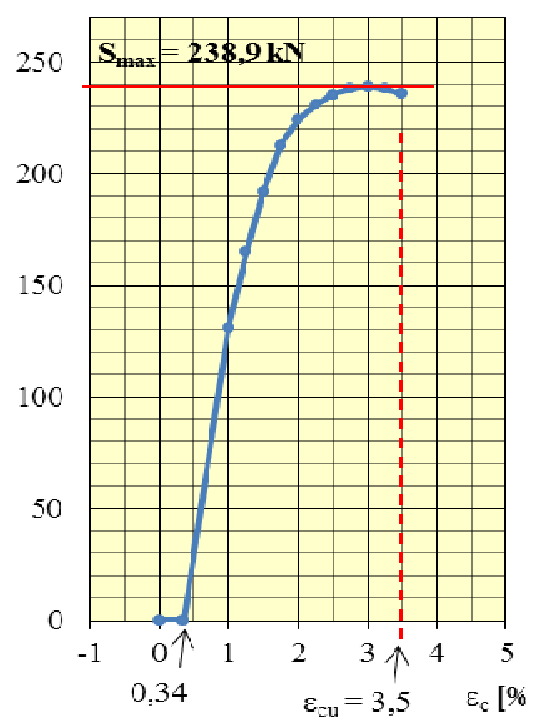

Figure 15. Shear Wall $D_{22}$. Computed $\left(S-\varepsilon_{c}\right)$ curve for the most compressed point of the base section

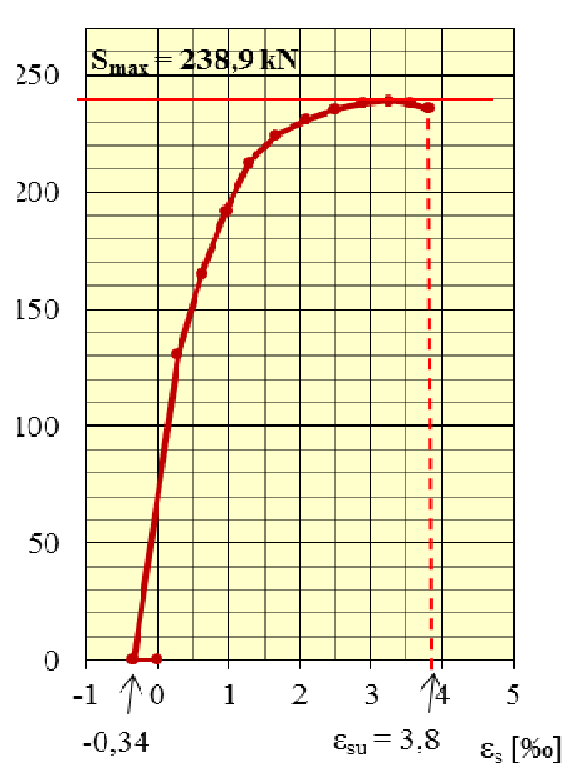

Figure 16. Shear Wall $D_{22}$. Computed $\left(S-\varepsilon_{s}\right)$ curve for the most tensioned reinforcement bars of the base section

There is a rather good agreement between the calculated and measured strain values, especially of the compressed concrete and mostly in the elastic range of loading, as it is found from the comparative curves plotted for the $\mathrm{D}_{22}$ wall specimen in Figures 17 and 18.

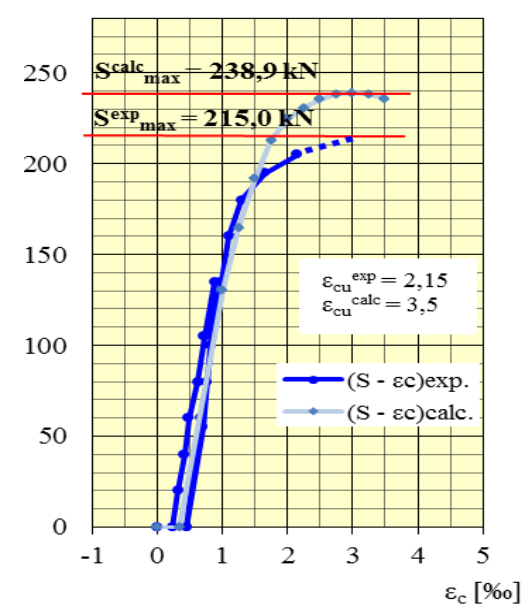

Figure 17. Shear Wall $\mathrm{D}_{22}$. Computed vs. experimental $\left(\mathrm{S}-\varepsilon_{\mathrm{c}}\right)$ curves for the most compressed point of the base section 


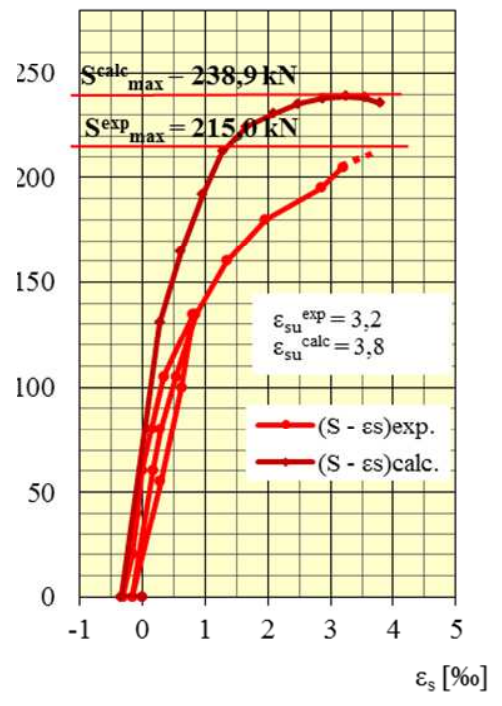

Figure 18. Shear Wall $\mathrm{D}_{22}$. Computed vs. experimental $\left(\mathrm{S}-\varepsilon_{\mathrm{s}}\right)$ curves for the most tensioned point of the base section

\subsection{Results and Discussions}

The reinforced concrete shear wall calculation method which represents the aim of this paper enables a complete calculation of a flexural governed reinforced shear concrete wall in its both main respects: strength capacity in flexure and top horizontal displacements. The two specimens calculations have shown the capacity of this method to predict the failure mode of the walls, which was at the compressed zone of the base cross-section, as shown in Figures 13 and 14. Regarding the displacements calculation, the method enables a unitary way of calculation in all loading stages, up to the failure, being able to make distinction between their two major components, due to flexure and shear. The values found for these components are confirmed by the latter experimental researches (Massone et al., 2004) having the aim to measure separately the flexural and shear components. It is important to point out that these vary in the same way, confirming the presence of a coupling of the inelastic flexural deformations and inelastic shear deformations. Only near the failure, at high values of the horizontal force, the shear component of the computed total displacement differed much from the flexural one, being even two times higher than the latter. The method also provides the basic means for a satisfactory prediction of the strains in concrete and steel reinforcement for the most part of the loading range. The comparison between computed and experimental results proved a good agreement concerning the strength capacity as it results from Table 2. Referring to the displacements values, it was proved a surprisingly good agreement in the elastic range. It is felt that the greater difference resulted in the inelastic range could originate in the influence of some factors which have not been considered by the model, such as: the horizontal sliding at the base of the wall, the greater width of the inclined cracks and the second order geometrical effects.
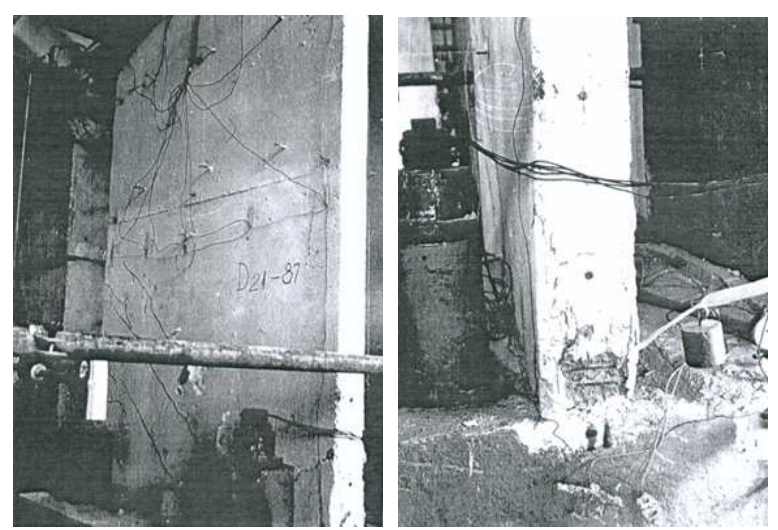

Figure 13. Shear wall $\mathrm{D}_{21}$. General view (left) and detailed view of the compressed zone degradation at the base cross - section (right)

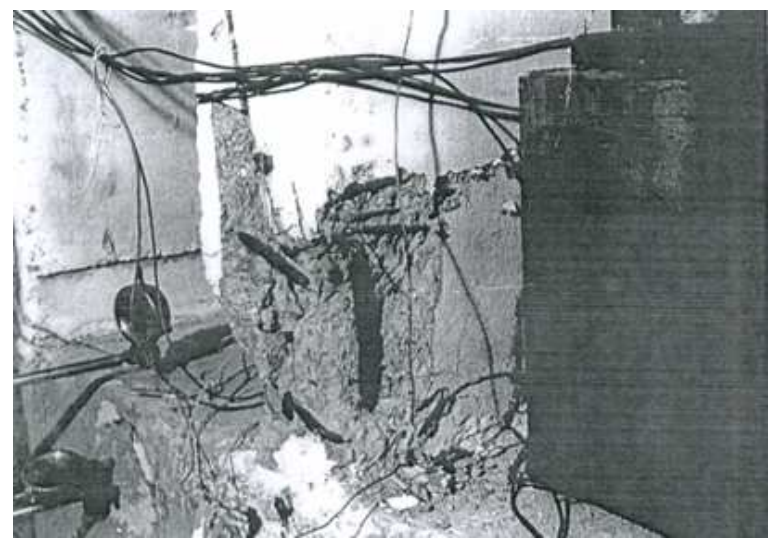

Figure 14. Shear wall $D_{22}$. Detail of the the degradation of the compressed zone of the base cross - section

\section{CONCLUSIONS}

As result of findings presented in this paper, there can be formulated the following conclusions:

- The calculation method of the reinforced concrete flexural governed shear walls presented above can be a useful tool for a rather accurate prediction of the behaviour of these important structural members, both in the elastic and inelastic range. The main characteristics of this behaviour are computed or revealed, such as: failure mode, strength capacity, flexural and shear displacements;

- The method takes into account the main factors which influence the behaviour of the structural walls: the shape of the cross-section, the constitutive curves for the concrete in compression and for reinforcement steel (in compression and in tension, considering the strengthening after yielding), the amount and the distribution of the reinforcement steel in the cross-section;

- The comparison between calculated and experimental results proved a rather good accordance but additional 
comparative work is required until a final conclusion could be formulated.

\section{REFERENCES}

Agent R., Postelnicu T., 1982, 1983. Calculul structurilor cu diafragme din beton armat, (Analysis of Structures with Reinforced Concrete Shear-walls) vol. I. elastic şi vol. II. Postelastic. Editura Tehnică, Bucureşti.

Bia C., Ille V., Soare M. V., 1983. Rezistenţa materialelor şi teoria elasticităţii. (Strength of Materials and Theory of Elasticity), Editura Didactică şi Pedagogică, Bucureşti.

Beyer K., Dazio A., Priestley M. J. N., 2011. Shear Deformations of Slender Reinforced Concrete Walls under Seismic Loading. ACI Structural Journal, March - April 2011, 108(2), pp. $167-177$.

Brînzan I., Trifa F., 1988. Cercetări și experimentări privind zveltețea inimii diafragmelor din beton armat monolit cu legături transversale pe contur. Referat cu concluzii. Completare prescripții tehnice și propuneri pentru proiectarea tip, (Researches and Experimentations regarding the Slenderness of the Reinforced Concrete Shear-wall Webs with Boundary Transverse Connections. Report with conclusions. Supplement of Design Provisions and Proposals for the Design of the Type Buildings). INCERC - LSC, București, Romania.

Ile N., Reynouard J. M., 2000. Nonlinear Analysis of Reinforced Concrete Shear Wall under Earthquake Loading. Journal of Earthquake Engineering, 4(2), pp. 183 - 213.

Ile N., Reynouard J. M., 2005. Behaviour of U - Shaped Walls Subjected to Uniaxialand Biaxial Cyclic Lateral Loading. Journal of Earthquake Engineering, 9(1), pp. 67 - 94.

Massone M. Leonardo, Orakcal K., Wallace W. John, 2004. Flexural and Shear Response in Slender RC Shear Walls. In: $13^{\text {th }}$ World Conference on Earthquake Engineering, Vancouver, B.C., Canada, August 1-6, 2004, Paper No. 1067.

Paulay T., Bachmann H., Moser K., 1990. Erdbebenbemessung von Stahlbetonhochbauten. Birkhauser Verlag, Basel;Boston; Berlin.

Palermo D., Vecchio F. J., 2002. Behaviour of Three Dimensional Reinforced Concrete Shear Walls. ACI Structural Journal, January - February 2002, 99(1), pp. $81-89$.

Park R., Paulay T., 1975. Reinforced Concrete Structures. John Wiley \& Sons Inc., New York.

Trifa Fl. S., Prada M., 2000. Metodă de calcul a capacităţii portante a secţiunilor diafragmelor din beton armat monolit, (Calculation Method of the Bearing Capacity of the Reinforced Concrete Shear-walls cross-sections). In: Analele Universităţii din Oradea, Fascicula Construcţii şi Instalaţii Hidroedilitare, TOM III., Oradea, Romania.
Trifa F. S., 2012. The Influence of Shear on The Inelastic Displacement of Eccentric Compressed Reinforced Concrete Members. Journal of Applied Engineering Sciences, Volume 2(15), Issue 1, University of Oradea Publishing House, pp. 123132.

Vecchio F. J., Collins M. P., 1986. The Modified Compression - Field Theory for Reinforced Concrete Elements Subjected to Shear. ACI Structural Journal, March -April 1986, 83(2), pp. $219-231$

*** EN 1992-1-1:2004. Eurocode 2: Design of concrete structures - Part $1-1$ : General rules and rulesfor buildings.

Nuclear Power Engineering Corporation of Japan, 1996. Comparison Report, Seismic Shear Wall ISP, NUPEC's Seismic Ultimate Dynamic Reasponse Test. Report No. NU-SSWISPD014,Organization for Economic Co-Operation and Development, Paris, 1996, 407 pp. 